\title{
Fótaskortur, forvarnir og félagsleg ábyrgð í hálkutíð
}

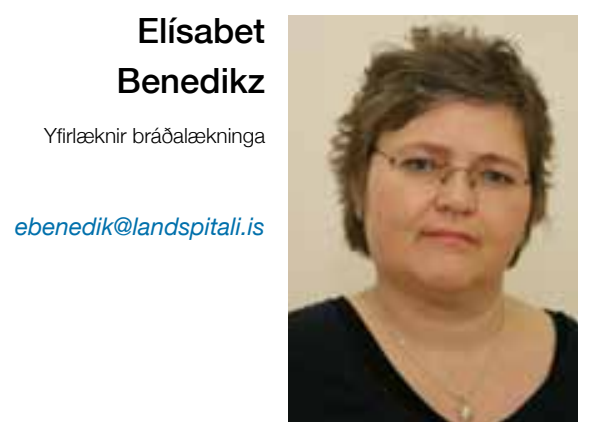

Tíðin hefur vægast sagt verið rysjótt pað sem af er ári. Að minnsta kosti er langt síðan vetrarríki hefur verið jafnmikið hér á suðvesturhorni landsins og undanfarna tvo mánuði. Eftir meira en áratug af mildum og snjóléttum vetrum eru íbúar höfuðborgarsvæðisins mikið til hættir að búa sig í samræmi við breiddargráðu borgarinnar. Við höfum komist upp með að ganga um á blankskóm og háum hælum árið um kring og ökum ekki lengur um á nöglum. Reyndar var haustið óvenjumilt, allt fram í nóvemberlok. Viðbrigðin eftir pað eru peim mun meiri.

Undanfarnar vikur hefur fryst, rignt, snjóað, rignt og fryst á ný. Petta er auðvitað uppskrift að skautasvelli enda hefur verið með eindæmum hált pað sem af er ári. Svo merkilegt sem pað er, kemur hálkan okkur alltaf jafn mikið á óvart. Við erum aldrei alveg tilbúin pegar hún skellur á, erum úti á blankskónum, ekki búin að setja vetrardekkin undir, bjartsýn á að komast samt klakklaust leiðar okkar. Pví miður heppnast pað ekki öllum sem skyldi. Annríki hefur verið mikið á bráđamóttöku Landspítala undanfarið. Sem dæmi má taka helgina 5.-7. janúar en pá komu hátt í 100 manns með hálkutengd slys, flestir vegna falls eða umferðaróhapps. Margir reyndust beinbrotnir eða líklega um og yfir 20 manns samkvæmt grófri talningu, flestir á efri eða neðri útlim. Sem betur fer urðu engin stórslys í umferðinni en mörg minniháttar óhöpp og eignatjón án efa talsvert.

Öllum pessum óhöppum fylgir umtalsverður kostnaður. Beinbrot getur pýtt vinnutap í 4-6 vikur, stundum lengur. Sem betur fer búum við í velferðarpjóðfélagi sem tryggir einstaklinga gegn áföllum og kostnaði sem pessum með lögbundnum veikindarétti og sjúkratryggingum. Рað er ekkert sjálfgefið, enda býr meirihluti mannkyns við allt önnur skilyrði og enga félagslega velferð af nokkru tagi. Skattar eru pað gjald sem við greiðum glöð fyrir pessi forréttindi. Petta pýðir auðvitað að hálkudagar eru samfélaginu dýrir. Ef við tökum einfalt dæmi frá fyrrnefndri helgi og segjum að pá hafi 20 manns með meðaltekjur (ca. 350.000 kr.) handleggs- eða ökklabrotnað, má reikna með vinnutapi í 6 vikur að meðaltali eða töpuðum launakostnaði upp á ríflega 10.000.000 kr. auk launatengdra gjalda (ca. 25\%), eða ca. 13.200 .000 kr. Pá er ótalinn kostnaður vegna meðferðar á sjúkrahúsi, endurhæfingar og mögulegs bótaréttar. Líklegt er pví að pessi tala sé umtalsvert hærri. Pá höfum við ekki byrjað að áætla kostnað vegna meiðsla eða eignatjóns vegna umferðaróhappanna.

Samfélagskostnaður og hagrænar afleiðingar fyrir vinnandi fólk eru ekki pær einu sem vert er að ræða. Fyrir aldraða getur beinbrot snúist um líf eða dauða; pað getur verið pað atvik sem verður til pess að viðkomandi getur ekki lengur búið heima og verður að fara á hjúkrunarheimili. Dánartíðni meðal aldraðra eftir lærleggshálsbrot er 15-20\% innan árs, svo dæmi sé tekið.

Eftir pessa umræddu helgi voru borgaryfirvöld harðlega gagnrýnd fyrir að ryðja ekki umferðaræðar nógu vel, hvorki fyrir akandi né gangandi/hjólandi. Pau virtust hafa haldið að sér höndum við að sanda og salta, báru pví við að pað tæki pví ekki í pessum vatnsflaumi. Má vera að pað sé rétt að salt og sandur skolist burtu jafnharðan í asahláku og að faglegar forsendur hafi verið að baki allri ákvarðanatöku um hreinsun. Eigi að síður parf að staldra við og vega pann kostnað sem sparast með aðhaldsseminni á móti mögulegum kostnaði vegna slysa, sem við vitum að munu verða í mikilli hálku og ófærð. Leiða má líkur að pví að pessi aðhaldssemi borgaryfirvalda hafi leitt til aukins samfélagskostnaðar annars staðar. Peim kostnaði hefur nú verið velt yfir á heimilin í landinu, rétt eins og ýmsum öðrum kostnaði á síðustu misserum.

Hreinsun akbrauta og gangstétta, að ógleymdum hjólastígum, er mikilvæg forvörn í hálkunni, ekki síður en góður skófatnaður og mannbroddar. Hér bera borgaryfirvöld mikla ábyrgð.

Ábyrgð borgaranna sjálfra má pó ekki gleymast pví margir virðast detta á sleipum bílaplönum og einkalóðum húsa sinna. Við berum umfram allt ábyrgð sjálf á eigin öryggi og velferð. Verum pví dugleg að moka, salta og sanda. Skóum okkur upp og notum mannbrodda. Keyrum varlega á vetrarbúnum bílum. Tileinkum okkur hið sérstaka ísgöngulag inúíta. Gamalt og farlama fólk haldi sig inni. Pá mega skokkarar og hjólreiðamenn ekki láta ófærðina hrekja sig út á akbrautirnar. Síst er nú áhættulaust að lenda á spítala. Рað er víst hættulegra en að stunda bæði teygjustökk og klettaklifur. Vonandi vorar bæði snemma og vel.

Icy streets; prevention and public responsibility Elisabet Benedikz MD, EDIC, MPA Chief of Emergency Medicine University Hospital 108 Reykjavík, Iceland 